Tenure, turnover and careers in the European Parliament: MEPs as policy-seekers

Richard Whitaker

ABSTRACT Given the considerable increase in its powers over recent decades this paper asks how far the European Parliament (EP) is an attractive place to build a legislative career. Using a theory of MEPs as policy-seekers, it shows that MEPs are indeed building careers in this supranational institution. Turnover is in decline in the EP and on its committees, average length of service has increased and greater proportions of MEPs aspire to stay than previously. Looking at the 30 years since direct elections began, policy influence and office benefits are associated with lower likelihood of exiting the EP while being on the geographical periphery of the EU makes MEPs more likely to leave.

KEY WORDS European Parliament, legislative careers, legislative turnover, MEPs, policyseeking, second-order elections. 


\section{Tenure, turnover and careers in the European Parliament: MEPs as policy-seekers}

\section{INTRODUCTION}

Given its increasing involvement in the European Union's (EU) legislative process, how much has the European Parliament (EP) become an attractive place for those wishing to build a legislative career? In the last 25 years the EP has moved from merely being consulted on legislation to having codecision rights with Council of the European Union in a wide range of policy areas including internal market legislation, environmental policy, the free movement of workers around the EU, and agricultural and fisheries policies. Members of the European Parliament (MEPs) whose primary aim is influencing policy therefore have many more opportunities to do so than when the first direct elections took place in 1979. Nevertheless, building careers in the EP is complicated by the second-order nature of EP elections, which often leaves MEPs frustrated at the lack of discussion of their work during and between election campaigns. This means careers might be ended by factors beyond MEPs' direct control such as whether their party happens to be in government and the political issues on the agenda in their member state.

So far there has been only a limited range of research on MEPs' careers. Scholars have asked whether the EP is simply a retirement home for national politicians, whether it is a stepping stone to a high profile career in national politics (Scarrow 1997; Westlake 1994b), whether a supranational elite is emerging in the EU (Verzichelli and Edinger 2005, Beauvallet and Michon 2010) and how much voting in the EP reflects progressive ambition (Meserve et al. 2009). Hobolt and Høyland (2011) examine how far national political experience helps parties to gain more votes at European compared with national elections. Such work remains 
a small subset of research on the EP with little study of MEPs' careers over a long time period. This paper represents the first systematic attempt to understand MEPs' careers over the 30 years from the beginning of direct elections. In the past, this has been a tricky subject to study due to a lack of data. Part of this problem is solved by Høyland et al's (2009) database of the EP which reads data from the EP's website on MEPs' committee, party and leadership positions. While these do not tell us what MEPs did after the left they institution, they can be used to provide information about careers in the EP from 1979 to the present. Looking at all electoral contests from the second direct elections to the Parliament in 1984 to the 2009 election, this paper assesses how long MEPs stay in the EP and how far policymaking opportunities are associated with MEPs staying in the EP across terms.

\section{PREVIOUS RESEARCH ON MEPS' CAREERS: THE DEVELOPMENT OF EUROPEAN CAREERISTS?}

The comparatively small amount of work on how far the EP is an attractive place to build a legislative career is surprising given the extension to the scope of its powers since the 1990s (Hix and Hoyland forthcoming). Among this body of work, Westlake (1994b) studied the careers of British MEPs in the 1979-92 period and showed that while some members were coming to the end of their political lives, many used the Parliament either as a stepping stone to national politics or as a place to develop a legislative career. Scarrow's (1997) study of French, German, Italian and UK MEPs from 1979-94 showed that roughly one-third had served for 1.5 terms or more and that over half the UK and German MEPs could be categorized as European careerists, serving for at least eight years in the EP. She concluded these figures were impressive given the youth of the EP as an institution and its changing 
responsibilities over that time. She argued this would provide a basis for the EP to be filled with careerists in future.

Verzichelli and Edinger (2005) studied the EP's 2004 intake looking for the emergence of a supranational elite. They note that 2004 saw the highest return of previous members up to that point, excluding those from the 10 new member states. They point out that new arrivals are becoming younger on average and that practices of systematic turnover within national parties are declining. Nevertheless, as Scarrow (1997) found, these patterns differ by member state. Beauvallet and Michon (2010) had similar aims and, although they also found national variation, they argued that stints in the EP have become more stable and lengthier. They suggest a European Parliamentary elite is emerging and that securing leadership offices in the EP increasingly requires EU-specific experience.

Addressing a slightly different question, Meserve et al. (2009) use Schlesinger's (1966) concepts of progressive and static ambition to understand MEPs' defection from their party group line. Progressive ambition describes a desire to further one's career beyond the legislature in a more senior political office. Static ambition represents the aim of remaining in a legislature and working up its hierarchy. They show that defection from the party group line is more likely among younger MEPs, who have the possibility of moving into a national career (progressive ambition), and older MEPs who have less need to impress party group leaders with their loyalty. Much of this research begs the question, why would MEPs want to stay in the EP for long periods of time and build a career there rather than attempt to move into their national political system where they mind find a legislative career more attractive? The next section develops a theoretical answer to this question. 


\section{THEORISING MEPS' CAREERS: WHY SHOULD MEPS WANT TO STAY IN THE EUROPEAN PARLIAMENT?}

One way of understanding MEPs' careers is to think of them in relation to vote, policy and office-seeking behaviour (Hix et al. 1999; Strøm 1990). A principal reason for wanting a career in the EP may be the policy influence that the EP affords. In her study of the EP's party system, Kreppel (2002: 23) theorises that policy goals are most likely to structure MEP behaviour, given the weak electoral connection in the EU. She argues that before the EP had much policy influence, MEPs' main policy goal would have been increasing the EP's legislative power. Once greater powers were granted, policy-seeking MEPs would attempt to influence the EU's legislative outputs using the new tools available to them. We hypothesize that policy-seeking legislators should be more likely to want to remain in the EP as its legislative power grows. This may be particularly the case for MEPs in the larger groups, which have a greater chance of affecting the outcomes of votes in the EP (Hix et al. 2007) and which gain larger numbers of rapporteurships than smaller EP groups (Mamadouh and Raunio 2003). A further implication of this theory is that policy-seeking MEPs should be more attracted to remaining on European Parliament committees the greater their degree of legislative activity. These committees are where the detailed legislative work of the EP is carried out (Neuhold 2001; Ringe 2010).

Office-seeking legislators may also perceive more reason to remain in the EP over time. As the EP's legislative influence has increased so has the significance of 'mega-seats' (Carroll et al. 2006). These are leading offices within a legislature. In the case of the EP, they include the presidency and vice-presidencies of the EP, chairs of committees, party group presidencies and the office of quaestor. The latter position includes responsibility for 
administration and financial matters for individual members. The EP President chairs sittings of the EP and the Conference of Presidents among other things. Vice-Presidents chair plenary sessions and take on other leadership responsibilities, and a subgroup of them are permanent members of the EP's conciliation committees, which meet when agreement cannot be reached at second reading in the ordinary legislative procedure. Holding such mega-seats may help members to make stronger claims about their records when seeking re-selection and re-election. We hypothesize that holding a mega-seat will increase chances of remaining in the EP from one election to another.

Nevertheless, there are costs to being an MEP. First, the amount of travel needed in order to attend business in Brussels and Strasbourg while maintaining a presence in the member state and/or district may amount to a great deal especially for those from the periphery of the EU. We therefore expect that MEPs from peripheral member states are more likely to exit the EP at the end of a term than others. Second, the enlargements of the EU mean that in many of the EP's terms since direct election there has been a group of MEPs from new member states who may have started their EP careers with limited knowledge about how the institution functions. On the basis that some may find the job is not as they anticipated it, we hypothesize that exiting the EP is more likely at the end of the first term in which an MEP's member state was in the EU. As institutional knowledge builds among a member state's MEPs, this problem should become less prominent.

All of the above assumes MEPs make their own choices about whether they stay beyond their first term of office in Brussels and Strasbourg. Several factors undermine this assumption. Studies of EP elections suggest that they largely conform to the second-order model in which, among other things, campaigns are dominated by national issues ${ }^{1}$ and governing parties do 
badly, except for when EP elections follow rapidly after national ones (e.g. Hix and Marsh 2007). So the likelihood of re-election may vary on the basis of factors beyond MEPs' direct control such as whether their national party is in government. We hypothesize that if an MEP's national party is in government this makes exit from the EP more likely but that - on the basis of previous research (Hix and Marsh 2007) - this effect will not hold if a European election occurs early in the cycle of national elections.

Electoral systems may also affect outcomes. Open list and single transferable vote (STV) systems allow voters to rank candidates within parties, leaving legislators more open to the possibility of defeat by a candidate from their own party than in closed list or single member plurality (SMP) systems (Matland and Studlar 2004). Where open ballot structures are used (STV and open list) we expect the likelihood of exit from the EP to be higher. We also expect the chance of a career ending to be greater where electoral volatility is higher such that party support among voters is less consistent. Overall then, we can expect that the EP has become a more attractive place for policy-seeking MEPs to build a career over time but that their ability to do this is affected by a range of other factors including geography, being a new member of the EU and political factors beyond the control of individual legislators.

This paper uses data on MEPs' stints in the EP from 1979-2009 to assess how far MEPs are building careers in the EP and the range of variables that explain whether MEPs stay in the institution. The next section looks at tenure in the Parliament and its committees to see how far there is a core of politicians serving long spells in the EP. A further section then examines exit from the EP in a multivariate analysis. Finally, some conclusions are drawn.

\section{TURNOVER AND TENURE IN THE EP}


This section starts to answer our research question by looking at tenure in the EP and its committees, changes in the age of MEPs over time and MEPs' career aspirations. To set this in context, Figure 1 shows the proportion of members who were new after each EP election since 1984. The figures are high when compared with the US Congress or Westminster, for instance, where mean incumbent success rates are closer to 70-80 per cent (Matland and Studlar 2004). The process is complicated by the expansion in the numbers of MEPs as a result of the enlargement of the EU from nine member states at the time of the first direct elections (1979) to 27 by 2007. Nevertheless, there has been a steady decline in the proportion of MEPs who are new since the high point after the 1994 elections.

[Figure 1 about here]

[Table 1 about here]

To examine MEPs' length of service, we use data derived from Høyland et al's (2009) database. Among MEPs from the first $15 \mathrm{EU}$ member states, the mean length of previous service in the EP has increased from 2.6 years among those elected in 1984, to 4.6 years among those elected in 2009. Although we might expect some increase in this number purely on the basis that in 1984 an MEP could only have served for five years at most (in this dataset), evidently, even with high turnover, MEPs' experience is increasing on average. If we restrict this to those who were incumbents the figures rise from 3.4 years at the 1984 election to 9.1 years of previous service in 2009 . 
Table 1 shows a breakdown of the length of MEPs' stints in the EP from 1979-2009.

Evidently, many of these stints have been for only one term, although it should be born in mind that these data include MEPs who are still serving. Around 40 per cent of MEPs'stints have lasted more than a single term and there is a core of roughly 16 per cent that have lasted for more than two terms. The data also show that the proportion of MEPs not completing full terms in the EP - perhaps leaving to go into national politics - has declined overall from 19 per cent in the first term (1979-84) to 12 per cent in term 6 (2004-9).

[Table 2 about here]

Previous evidence (Scarrow 1997) suggests there are considerable variations in tenure by country. Looking only at the first 15 member states of the EU, Table 2 shows the proportion of each country's MEPs who have served particular lengths of time. The table excludes those who started in the EP after December 1999 as such MEPs could not have served for two full terms or more by the point at which the dataset ends in December 2009. The UK tops the list for the percentage of stints that have lasted for two full terms or more, followed by the Netherlands, Germany and Denmark. At the bottom are Sweden and Greece with 86-87 per cent of their members' stints having lasted less than two full terms. These results are similar to those of Scarrow (1997).

What might explain these national variations? Some of the answer lies in how long these countries have been in the EU. Electoral systems may also make a difference in that the ballot structure is closed or ordered in some of the countries towards the top (UK, Netherlands, Germany and Spain). Other cases run against this, such as Ireland, which is in the upper part of the table but where the open ballot structure of the STV system is in place. Scarrow (1997) 
argues national variations are partly related to how an EP career fits with national political careers. She notes that in the UK and Germany there is a bigger divergence between the two career paths. In addition, there has been more of a tradition in some countries, such as France, to put high profile candidates at top of lists but then to substitute them with other politicians, part way into an EP term.

\section{Tenure in the EP's committees}

The data also allow us to look at stints not just in the EP as a whole but in its committee system where the detailed legislative work of the Parliament takes place (Neuhold 2001; Ringe 2010). If MEPs are engaging in policy-seeking behaviour we would expect them to want to remain on EP committees that have policy influence. Table 3 shows how the proportion of stints lasting more than five years (one term) varies by committee. The ranking we see here makes sense in terms of MEPs pursuing policy goals. For instance, the Environment committee is the most legislatively active of all the EP's committees. Budgets has also been one of most powerful EP committees over time, particularly, in relative terms, during time when EP had no or very little legislative power (Corbett et al. 2003). Foreign Affairs has often been a highly sought after committee, frequently chosen by the largest groups early in the process of allocating chairs (Corbett et al. 2007). It lacks legislative power but is nevertheless viewed as highly prestigious. Agriculture and Fisheries are two of the committees with the most obvious link to constituency interests (defined broadly here such that may refer to an entire whole member state). The committees at bottom of list, by contrast, are mainly those that lack much involvement in the ordinary legislative procedure.

[Table 3 about here] 
In addition to this, turnover on committees has declined over time. If we include all MEPs, the proportion staying in the same committee position after an election has risen slightly from 18.7 per cent from the first into the second term to 20.4 per cent across the sixth and seventh terms. Given the comparatively high turnover in the EP these figures are understandably quite low. If we look only at those who stayed in the EP across terms the figures are higher and the difference over time bigger too, rising from 38.9 per cent of MEPs staying in the same committee positions in the changeover from terms $1-2$ to 48.5 per cent in the transition from the sixth to seventh terms. This evidence suggests some MEPs pursue careers involving spells on the same committee for a reasonable period of time. The variations in this by committee also make sense in terms of MEPs pursuing policy goals.

\section{MEPs' age and aspirations}

We can understand more about how far the EP is an attractive place to build a career by looking at whether MEPs are starting their careers at a younger age and what their aspirations are. Data derived from Høyland et al's EP database show that the average age of MEPs has declined from 52 for those starting in the first elected term (1979), to 49 for those starting in term seven (2009-14). At the upper end of the age range, those who are 65 or over made up 10 per cent of those starting in 1979 but only 4 per cent of those starting in the EP 30 years later. This is consistent with fewer politicians viewing the EP as a retirement home, and more seeing it either as a career in itself or a stepping stone to a national career.

Taking a lead from Hibbing (1999), we look at what MEPs say they want to do in terms of career, not just what they actually do. The European Parliament Research Group carried out surveys of MEPs in 2000, 2006 and 2010 (Farrell et al. 2011). We use a question that asked 
'what would you like to be doing in ten years' time?' from which respondents could select as many options as they wanted.

[Figure 2 about here]

Figure 2 shows a large decline in those saying they would like to be retired. This makes sense if the EP is seen as a more attractive career option and if there are fewer older MEPs over time, as we have seen. Roughly 30 per cent said in 2010 that they still wanted to be an MEP in a decade's time. This gives some sense of the proportion of members who see their careers primarily in the EP, at least for ten years ahead. Proportions stating they wanted to be a member of a national parliament or national government are lower. But clearly there are still many MEPs who do not see themselves as staying at the EP for a long period. This is somewhat consistent with the proportion of MEPs who only stay for one term.

Taken together, the evidence presented here is consistent with the EP being seen as a place to build a career in terms of the greater mean length of service, falling turnover of committee positions and longer stints on more legislative active committees, MEPs' declining average age, falling proportions of older MEPs and members' aspirations. Nevertheless, a number of factors may conspire against MEPs building careers in the EP, as noted earlier. The next section takes account of these with a multivariate analysis.

\section{EXPLORING MEPS' CAREERS}

\section{Expectations and data}

This section analyses incumbent success in the EP for the period 1979-2009. Following BoxSteffensmeier and Jones $(1997 ; 2004)$ we estimate a discrete-time model using logistic 
regression. The event being studied is whether an MEP returns to the EP at each election time from 1984-2009. Each case represents an MEP at a particular election point. The dependent variable is coded 1 if an MEP does not return to the EP after an election, and 0 if the MEP does return. All MEPs entering the EP from 1979 until just before the end of the fifth term (1999-2004) are included in the analysis. This cutoff point for MEPs was chosen in order to reduce right-censoring, a problem relating to the fact that, at present, we cannot know the failure time of MEPs who are currently serving in the EP. MEPs initially enter the risk set once they come up for election the first time. Their electoral success is measured at each electoral contest thereafter until the MEP fails to return to the EP. MEPs who serve two or more stints in the EP - that is, periods of service punctuated by gaps - re-enter the risk set each time they come up for election. This gives us 3,733 cases in which 55 per cent $(n=2,069)$ score 1 on the dependent variable.

MEPs might fail to return to the EP either because they are defeated, they retire or choose to change their career. To explain each of these outcomes we would need a comprehensive dataset of MEPs' post-EP careers across the 1979-2009 period. Such data do not yet exist. Nevertheless, we can still test for the effects of a range of factors on the likelihood of MEPs' careers in the EP coming to an end.

We consider several factors related to policy-seeking behaviour. First, we look for the effects of being part of one of the larger party groups. Hix et al. (2007) show how, as party group size increases, cohesion (measured by behaviour in roll-call votes) rises. The explanation for this is that as party groups become bigger, their chances of influencing outcomes in EP votes increase, hence they have a greater incentive to vote together. Due to the distribution of positions on the basis of group size in the EP, career advancement may also be easier within 
the larger groups. Applying this logic to the decision to attempt to stay in the EP, we expect that MEPs from larger party groups are more likely to remain in the EP after an election, once other factors are taken into account. Dummy variables for the three largest party groups in the EP (the European People's Party (EPP), the Progressive Alliance of Socialists and Democrats (S\&D) and the Alliance of Liberals and Democrats for Europe (ALDE)) are included in the model.

Individual MEPs may also be able to enhance their chances of achieving policy influence if they held a mega-seat in the EP during the previous term. Holding such an office should provide incentives for MEPs to want to remain in the EP rather than exit voluntarily on the basis that leaving might mean losing the opportunity to achieve the influence that these positions afford. Holding such offices might also be advertised in election campaigning as an indicator of an MEPs' seniority in the EP. For these reasons we expect a negative relationship between holding a leadership office and the likelihood of failure to return to the EP. This is tested with a dummy variable measuring whether an MEP held the office of President or Vice-President of the EP, committee chair, party group leader or quaestor.

MEPs may also be more likely to achieve policy influence with a position on the most highly valued committees in the EP. Ringe (2010) shows how committee members are central to the formation of national party and party group positions on legislation in the EP. This is likely to be particularly important for committees that are prized by the major party groups, normally those with amongst the most legislative involvement or with the greatest prestige. We can measure which committees are most valued by the two largest party groups (the EPP and S\&D) by checking the first two committees chosen by these two groups when chairs are distributed at the start of each EP term. Committee chairs in the EP are distributed in 
proportion to party group size using the D'Hondt formula. Larger parties will have more choices early in the process. For instance, after the 2009 elections, the EPP, as the largest group, was entitled to the first, third, fifth, seventh, eleventh, thirteenth, fifteenth, eighteenth and twentieth choices of committee chairs (Corbett et al. 2011). We therefore include a dummy variable for MEPs who served on one of the top two choices of committee for the EPP and S\&D in the previous term. ${ }^{2}$ These choices change by term and allow us to measure the effect of being on a committee that was deemed significant in a particular parliamentary term. Information about party group's order of committee choice was taken from Clark and Priestly (2012: 197), Corbett et al. (1995), Jacobs et al. (1990) and Judge and Earnshaw $(2003,2008)$. We expect membership of one of these committees in the previous term to be associated with lower likelihood of MEPs leaving the EP.

MEPs might also have been more likely to want to stay in the EP after the codecision procedure was introduced, as this offers the EP co-legislative power with the Council of the EU in the areas to which it applies. A dummy variable for MEPs up for re-election in 1994 or later is included.

As noted earlier, there are costs to being an MEP which must be taken into account in any model of whether members return to the institution. To test the proposition that greater travel times will make MEPs less likely to seek re-election, a dummy variable is included for countries on the geographical periphery of the EU (Ireland, Portugal, Spain, Italy, Cyprus, Malta, Greece, Bulgaria, Lithuania, Latvia, Estonia and Finland). We expect members from these countries to be more likely not to return to the EP after elections. We also test whether there is a member state first term effect, i.e. if a member state joined the EU during the term prior to the election (measured by a dummy variable), is the likelihood of not returning to the 
EP any higher? We expect that inexperience with the EU and its institutions means some members choose not to return after their first term but that once this first term has passed, the proportion of such members declines as politicians from the member state gain a more accurate idea of what working in the EP is like. We would therefore expect a positive relationship between this variable and the likelihood of not returning to the EP.

Several factors which are beyond the direct control of MEPs may also be expected to affect our dependent variable. To test for the effects of electoral systems in the EP (see Farrell and Scully 2007 for more on this), dummy variables were included for different types of ballot structure: single member plurality, closed party lists, ordered lists (where voters have some opportunity to rank candidates within parties but where there are restrictions on whether this affects electoral outcomes), fully open lists and the single transferable vote. Following Matland and Studlar (2004), we expect higher likelihood of failure to return to the EP where defeat by another candidate from the same party is more likely, as in the most open ballot structures (open lists and STV). Data on electoral systems were taken from Bowler and Farrell (1993), Corbett et al. (2000, 2011), Farrell and Scully (2007), Lodge (2010), Nugent (1995, 1999, 2010), Westlake (1994a) and the Sussex European Institute European Parliament Election Briefings. ${ }^{3}$

The second-order elections model suggests that whether a party is in government will make a difference to its fortunes in European elections (Marsh 1998; Reif and Schmitt 1980). On the basis that they perceive less to be at stake in European compared with national elections, voters may choose to vote against their favoured party in order to send a signal of dissatisfaction to its leadership. This, it is argued, is most likely to affect parties in government, hence the expectation that MEPs from governing parties are more likely to fail 
to return to the EP. To test this, a dummy variable is included measuring whether an MEP's party was in government at the time of the European election. There is evidence that the timing of EP compared with national elections mediates the effects of being in government. Governments facing European elections early in their lifetime may still be in a honeymoon period. As time draws on they may become less popular. To test for the effect of timing, the government variable is interacted with a dummy measuring whether the national election occurred within a period of twelve months prior to the European election. Data on parties in government and the timing of elections were taken from Woldendorp et al. (2000) and from the Election World pages on Wikipedia (http://en.wikipedia.org/wiki/User:Electionworld/Electionworld).

On the basis of previous research (Matland and Studlar 2004), we can expect electoral volatility to affect legislative careers. Higher levels of volatility should be associated with a greater chance of MEPs exiting the EP. We calculate volatility using the Pedersen index (Pedersen 1979) with data drawn from the Election World pages on Wikipedia noted above, special issues of Electoral Studies dealing with European elections, and, for the UK, from House of Commons Research papers on European elections.

Finally, in order to account for duration dependency in the data (Box-Steffensmeier and Jones 2004: 174), a variable is included for the number of terms an MEP has served at the point at which their electoral success is measured. We control for the effects of age with a variable measuring age at the time of the relevant election. Older MEPs are expected to have a greater likelihood of failure.

\section{Results}


Table 4 presents the output of the discrete-time logistic regression model. The results indicate that many of the factors related to policy-seeking behaviour have the expected effects on our dependent variable as does one of the costs associated with membership of the EP. First, membership of a key committee in the term before the election at which the dependent variable is measured, is associated with a lower likelihood of leaving the EP. Similarly, holding a leadership office in the EP also reduces the likelihood of exit. This may indicate that such senior MEPs are more likely to want to return on the basis of the influence or prestige of their position, and/or that they are able to benefit from their seniority in election campaigning. The effects of the party group dummies are as expected in that being part of one of the largest two groups in the EP is associated with lower likelihood of failing to return to the EP compared with membership of a group other than the three largest ones.

Nevertheless, we cannot make the same inference about the ALDE group, which has often been considerably smaller than even the second-placed party in the EP over time. The sign of the variable measuring cases at elections in 1994 and later is as anticipated but the coefficient is not statistically significant. It may be that MEPs had a greater desire to stand for election on and after this point, on the basis of the EP's greater legislative involvement but without modelling the decision to stand, rather than whether or not MEPs were re-elected, we cannot test this.

One of the costs we identified earlier affects the likelihood of not returning to Brussels and Strasbourg. The coefficient for the variable measuring countries on the geographical periphery of the EU is positive and statistically significant indicating, in line with our expectations, that MEPs from countries the furthest from Brussels are less likely than others to return to the EP after an election. While the sign for cases where an MEP's member state joined the EU in the term prior to an election is positive, as we would expect, the coefficient 
does not reach conventional levels of statistical significance so we cannot be certain of the notion that that there is something of a shake-up after these countries' first terms in the EP.

[Table 4 about here]

Electoral system effects are mixed. While the signs on three of the four ballot structure variables are as expected, only two of them reach conventional levels of statistical significance. Where the single member plurality system applies, MEPs are more likely to return to the EP compared with the those elected under closed party lists. While neither of these systems allow voters to rank candidates, stability appears to be higher under SMP. We should be careful in interpreting this result though as it acts as a dummy variable for cases of Great Britain prior to 1999 as these are the only ones where this system applies. Interestingly, the coefficient for the STV dummy variable is negative and significant at the $p<0.05$ level indicating that where STV is in use, MEPs are more likely to return to the EP than where closed party lists operate. These results may be affected by the comparative stability of two of the cases where STV operates, Northern Ireland and Malta.

We lack clear evidence of second-order election effects here as our measures of whether parties are in government and whether European elections happen early in the national electoral cycle do not appear to explain exit from the EP, although the signs of the coefficients are in the expected direction. Instead - and as hypothesized - levels of electoral volatility are strongly statistically significant in explaining the likelihood of MEPs leaving the EP. Finally, our control for age has the expected effect with older MEPs more likely to exit the Parliament. 
In summary, whether MEPs leave the EP or not appears to be affected by factors linked to policy and office-seeking behaviour. MEPs from the largest two groups, those holding leadership positions and those with assignments to key committees are more likely to return to the EP than others. The incentives to stay may increase over time given what we know from other work that experience in the EP is positively associated with gaining committee chairs and other leadership positions (Beauvallet and Michon 2010; Whitaker 2011). Those experiencing the costs of being on the geographical periphery of the EU are less likely to return. Institutional effects in the form of electoral systems are also present although these are more limited than expected. Finally, electoral volatility, something that MEPs can do little about, affects exit from the EP.

\section{CONCLUSIONS}

Amid talk of the decline of legislatures, the EP stands out as an institution whose legislative powers have increased over time. At the same time as this development, the evidence presented here from 30 years of the elected EP suggests that we are seeing careers being built in Brussels and Strasbourg. Turnover in the EP is comparatively high but is slowly on the decline. This makes sense if the EP is becoming a more attractive option for a legislative career. Many MEPs are present only for a term or slightly less although the proportion leaving before the end of a term has declined. This leaves a moderately-sized group of MEPs who have served for ten or more years, fewer older MEPs and smaller proportions wanting to retire. The average length of service of MEPs has increased, turnover on committees has fallen and we see longer committee stints making up larger proportions of stints on the more legislatively active committees. This is consistent with results of other research showing that MEPs have greater chances of achieving the significant position of committee chair or vice- 
chair (Whitaker 2011) and other leadership positions (Beauvallet and Michon 2010) when they have longer service in the chamber.

When we consider whether MEPs remain in the EP across terms, a range of factors related to policy and office-seeking behaviour explain variation. Being from one of the two largest groups, assignments to the most prized committees and holding an EP leadership position all increase the chance of returning to the EP after an election. Costs in terms of travel time appear to make exit more likely. As in other research on legislative careers, electoral volatility also affects the likelihood of MEPs exiting the EP.

More broadly, the findings suggest that we are starting to see the development of a European Parliamentary élite. This makes sense on the basis that the EP has become far more deeply involved in the details of the European Union's legislative process in the last 25 years or so and is therefore a more attractive place for policy-seeking legislators. It also provides some evidence, but which would require further research in other contexts, that granting legislative powers to a parliament does make it a more attractive place to build a legislative career. Nevertheless, to understand this fully we need to look at how MEPs' careers fit with those in the national arena and in particular, we need to know far more about what MEPs do after they leave the EP. For some, the attractions of a national political career may outweigh those of the EP even with its increased legislative role. Understanding this can only be done with comprehensive data on MEPs' post-EP careers which would allow for a study of progressive, discrete and static ambition (Schlesinger 1966) in the case of the European Parliament. This must be the subject of future research. 
Figure 1 Turnover at European Parliament elections

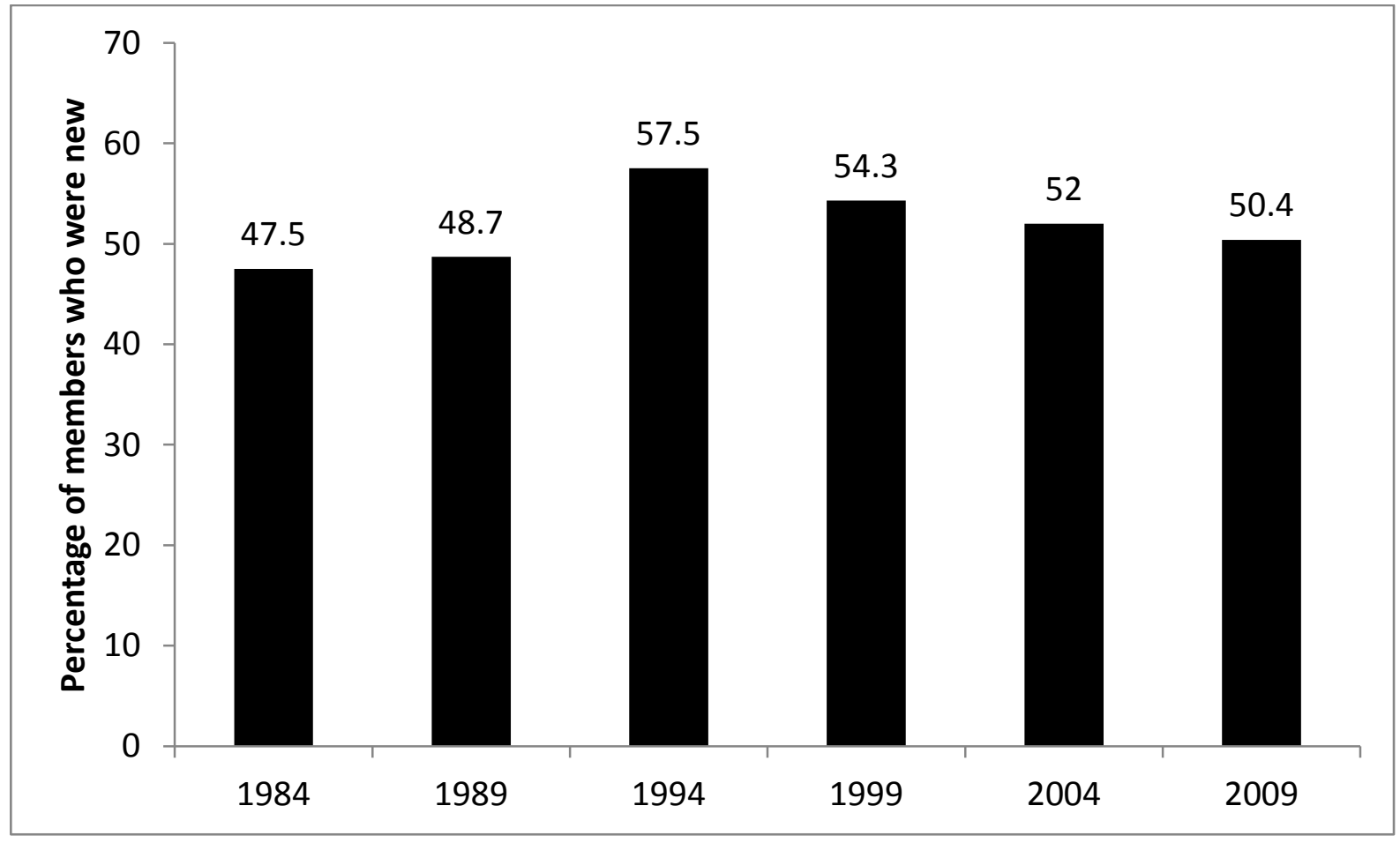

Sources: Corbett et al. (1995, 2007, 2011); European Parliament (1999); Wood (1984).

Figure 2 MEPs' career preferences

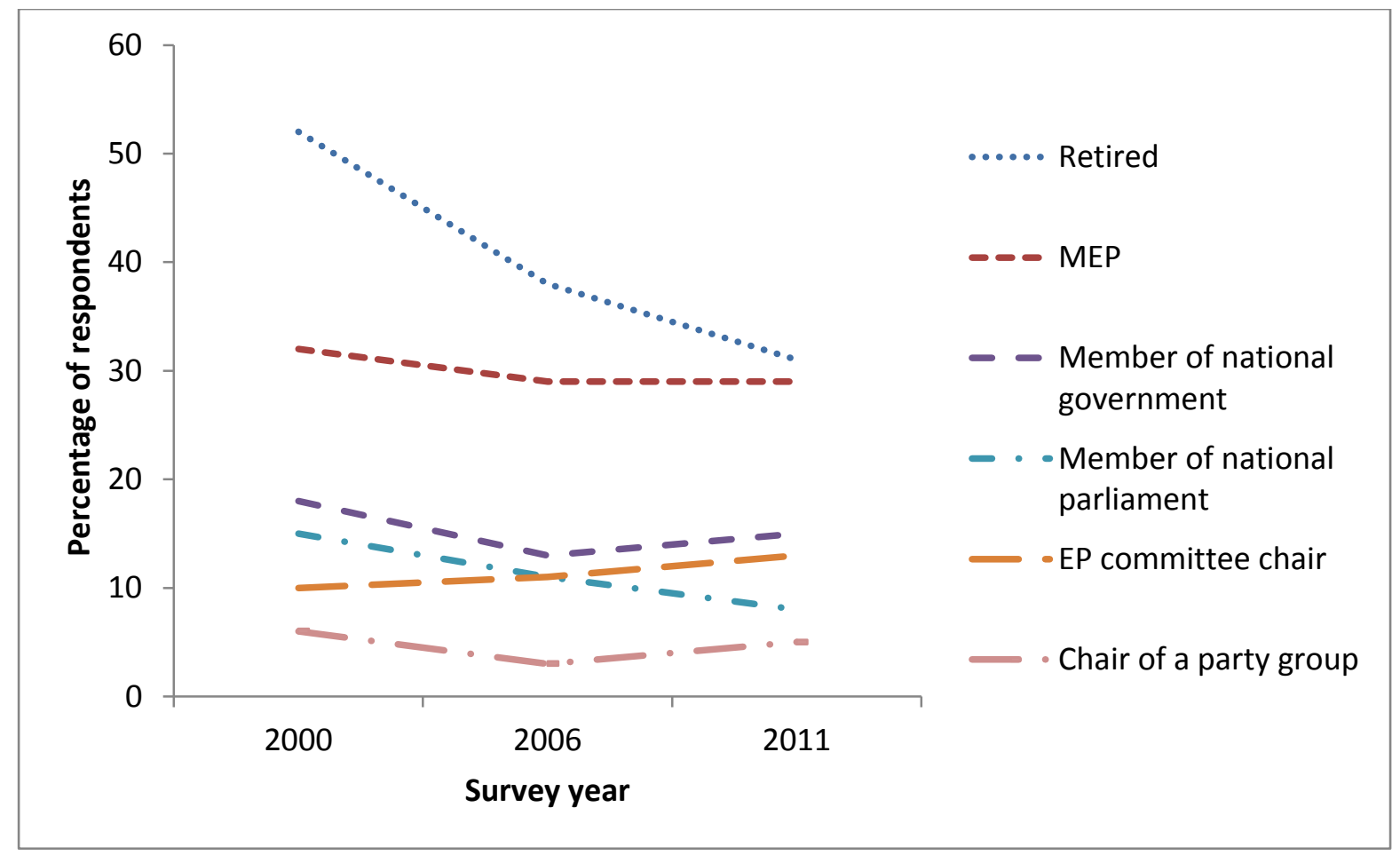

Source: Farrell et al. (2011). 
Table 1 MEP stints, 1979-2009

\begin{tabular}{lcr}
\hline & Percentage & \multicolumn{1}{c}{$\mathrm{n}$} \\
\hline Up to 5 years & 59.9 & 1852 \\
5 to 10 years & 23.4 & 724 \\
10 to 15 years & 12.3 & 380 \\
15 to 20 years & 2.9 & 89 \\
20 to 25 years & 1.0 & 32 \\
25 to 30 years & 0.4 & 12 \\
More than 30 years & 0.0 & 1 \\
\hline
\end{tabular}

Table 2 Tenure in the European Parliament among the EU15, 1979-2009

\begin{tabular}{lcc}
\hline & $\begin{array}{l}\text { Less than two full } \\
\text { terms (percentage of } \\
\text { MEP stints) }\end{array}$ & $\begin{array}{l}\text { Two full terms or } \\
\text { more (percentage of } \\
\text { MEP stints) }\end{array}$ \\
\hline United Kingdom & 31.5 & 68.5 \\
Netherlands & 41.0 & 59.0 \\
Germany & 49.2 & 50.8 \\
Denmark & 58.5 & 41.5 \\
Ireland & 60.8 & 39.2 \\
Spain & 65.7 & 34.3 \\
Belgium & 68.5 & 31.5 \\
Austria & 72.7 & 27.3 \\
Italy & 73.4 & 26.6 \\
France & 73.9 & 26.1 \\
Luxembourg & 74.1 & 25.9 \\
Portugal & 78.4 & 21.6 \\
Finland & 79.4 & 20.6 \\
Sweden & 86.4 & 13.6 \\
Greece & 86.6 & 13.4 \\
\hline Note: excludes those & intarting & 1999.
\end{tabular}

Note: excludes those starting in the EP after December 1999. 
Table 3 Committee tenure in the European Parliament 1979-2009

\begin{tabular}{lc}
\hline Committee & \% of stints over five years \\
\hline Agriculture & 27.2 \\
Environment & 25.5 \\
Foreign Affairs & 22.1 \\
Budgets & 21.0 \\
Fisheries & 20.5 \\
Employment and social affairs & 20.3 \\
Economics & 19.3 \\
Development & 17.3 \\
Energy & 17.2 \\
Transport & 17.1 \\
Women's rights & 15.5 \\
Civil liberties & 15.3 \\
Legal Affairs & 14.6 \\
Rules of procedure & 12.4 \\
External economic relations & 12.2 \\
Budgetary Control & 11.9 \\
Petitions & 11.2 \\
Regional policy & 10.0 \\
Culture & 9.3 \\
Constitutional Affairs & 8.2 \\
\hline
\end{tabular}

Note: covers only committees that have existed for 10 years or more and only MEPs who started a committee position by 30 Nov 2004 
Table 4 A discrete-time model of EP careers (logistic regression)

\begin{tabular}{|c|c|c|}
\hline Independent variable & Coefficient & Standard error \\
\hline Duration (number of terms in EP) & 0.01 & 0.05 \\
\hline Age & $0.05 * * *$ & 0.00 \\
\hline Member of key committee in previous term & $-0.24 * * *$ & 0.07 \\
\hline Holder of a leadership office in the EP & $-0.43 * * *$ & 0.14 \\
\hline \multicolumn{3}{|l|}{ Party groups: } \\
\hline European People's Party & $-0.57 * * *$ & 0.10 \\
\hline Alliance of Socialists and Democrats & $-0.28 * * *$ & 0.09 \\
\hline Alliance of Liberals and Democrats for Europe & -0.16 & 0.14 \\
\hline MEP up for election in 1994 or later & -0.13 & 0.09 \\
\hline MEP from a peripheral member state & $0.48 * * *$ & 0.10 \\
\hline MEP's member state is new entrant to EU & 0.20 & 0.15 \\
\hline Electoral volatility & $0.02 * * *$ & 0.00 \\
\hline \multicolumn{3}{|l|}{ Electoral system ballot structures (ref: closed party lists) } \\
\hline Single member plurality & $-0.80 * * *$ & 0.16 \\
\hline Ordered & 0.04 & 0.12 \\
\hline Open & 0.10 & 0.11 \\
\hline Single transferable vote & $-0.59 * * *$ & 0.22 \\
\hline National party in government & 0.13 & 0.09 \\
\hline National party in government*Early & -0.12 & 0.17 \\
\hline $\begin{array}{l}\text { Early [EP election in first year of national electoral } \\
\text { cycle] }\end{array}$ & -0.11 & 0.12 \\
\hline Constant & $-2.45 * * *$ & 0.24 \\
\hline \multicolumn{3}{|l|}{$n=3511$} \\
\hline Likelihood ratio $\chi^{2}$ test $=325.41 * * *$ & & \\
\hline
\end{tabular}

Notes: dependent variable coded 1 if an MEP does not return to the EP after an election, 0 otherwise. $* \mathrm{p}<0.1, * * \mathrm{p}<0.05, * * * \mathrm{p}<0.01$ 
Biographical note: Richard Whitaker is a lecturer in European politics at the University of Leicester, UK.

Address for correspondence: Dr Richard Whitaker, Department of Politics and International Relations, University of Leicester, University Road, Leicester, LE1 7RH, United Kingdom. Email: rcw11@ @leicester.ac.uk.

\section{ACKNOWLEDGEMENTS}

I am grateful to Shane Martin, Christopher Kam and the journal's anonymous referees for helpful comments on earlier versions of this paper.

\section{NOTES}

\footnotetext{
${ }^{1}$ However, some more recent studies indicate that attitudes to and party positions regarding European integration do have some effects on voters in European elections (Hix and Marsh 2007; e.g. Ferrara and Weishaupt 2004; Hobolt et al. 2009).

${ }^{2}$ These committees were: Foreign Affairs, Budgets, Agriculture and Economics during the first two terms. For the third, fourth and fifth terms they were the same except Environment replaced Agriculture. For term six they were Foreign Affairs, Economics, Environment and International Trade.

${ }^{3}$ These are available at http://www.sussex.ac.uk/sei/research/europeanpartieselectionsreferendumsnetwork/europepa rliamentelections.
} 


\section{REFERENCES}

Beauvallet, W. and Michon, S. (2010) 'Professionalization and socialization of the members of the European Parliament', French Politics, 8(2): 145-65.

Bowler, S. and Farrell, D. (1993) 'Legislator shirking and voter monitoring: impacts of European Parliament electoral systems upon legislator/voter relationships', Journal of Common Market Studies, 31(1): 47-71.

Box-Steffensmeier, J.M. and Jones, B.S. (1997) 'Time is of the Essence: Event History Models in Political Science', American Journal of Political Science, 41(4): 1414-1461.

Box-Steffensmeier, J.M. and Jones, B.S. (2004) Event History Modelling: A Guide for Social Scientists, Cambridge: Cambridge University Press.

Carroll, R., Cox, G.W. and Pachón, M. (2006) 'How Parties Create Electoral Democracy, Chapter 2', Legislative Studies Quarterly, 31(2): 153-74.

Clark, S. and Priestley, J. (2012) European's Parliament: People, Places, Politics, London: John Harper.

Corbett, R., Jacobs, F. and Shackleton, M. (1995) The European Parliament, $3^{\text {rd }}$ edn, London: Cartermill.

Corbett, R., Jacobs, F. and Shackleton, M. (2000) The European Parliament, $4^{\text {th }}$ edn, London: Cartermill. 
Corbett, R., Jacobs, F. and Shackleton, M. (2003) 'The European Parliament at Fifty: A View from the Inside', Journal of Common Market Studies, 41(2): 353-373.

Corbett, R., Jacobs, F. and Shackleton, M. (2007) The European Parliament, $7^{\text {th }}$ edn, London: John Harper.

Corbett, R., Jacobs, F. and Shackleton, M. (2011) The European Parliament, $8^{\text {th }}$ edn, London: John Harper.

European Parliament (1999) 'Results and Elected Members', EP Document PE 280.462/EN, Brussels: Directorate-General for Information and Public Relations.

Farrell, D.M. and Scully, R. (2007) Representing Europe's citizens? Electoral institutions and the failure of parliamentary representation, Oxford: Oxford University Press.

Farrell, D., Hix, S. and Scully, R. (2011) EPRG MEP Survey Dataset: 2011 release, http://www2.1se.ac.uk/government/research/resgroups/EPRG/MEPsurveyData.aspx

Ferrara, F. and Weishaupt, J.T. (2004) 'Get your act together. Party performance in European Parliament elections', European Union Politics, 5(3): 283-306.

Hibbing, J.R. (1999) 'Legislative careers: why and how we should study them', Legislative Studies Quarterly, 24(2): 149-171. 
Hix, S. and Høyland, B. (forthcoming) 'Political Behaviour in the European Parliament' in S. Martin, T. Saalfeld and K. Strøm (eds), The Oxford Handbook of Legislative Studies, Oxford: Oxford University Press.

Hix, S. and Marsh, M. (2007) 'Punishment or protest? Understanding European Parliament elections', Journal of Politics, 69(2): 495-510.

Hix, S., Noury, A.G. and Roland, G. (2007) Democratic politics in the European Parliament, Cambridge: Cambridge University Press.

Hix, S., Raunio, T. and Scully, R. (1999) 'An institutional theory of behaviour in the European Parliament', European Parliament Research Group Working Papers, 1, http://www.lse.ac.uk/collections/EPRG/pdf/Working\%20Paper\%201.pdf.

Hobolt, S.B. and Høyland, B. (2011) 'Selection and Sanctioning in European Parliamentary Elections', British Journal of Political Science, 41(3): 477-98.

Hobolt, S.B., Spoon, J. and Tilley, J. (2009) ‘A Vote Against Europe? Explaining Defection at the 1999 and 2004 European Parliament Elections', British Journal of Political Science, 39(1): 93-115.

Høyland, B., Sircar, I. and Hix, S. (2009) 'An Automated Database of the European Parliament', European Union Politics, 10(1): 143-152. 
Jacobs, F. Corbett, R. and Shackleton, M. (1990) The European Parliament, London: Longman.

Judge, D. and Earnshaw, D. (2003) The European Parliament, Basingstoke: Palgrave.

Judge, D. and Earnshaw, D. (2008) The European Parliament, $2^{\text {nd }}$ edn, Basingstoke: Palgrave.

Kreppel, A. (2002) The European Parliament and supranational party system: a study in institutional development, Cambridge: Cambridge University Press.

Lodge, J. (2010) (ed) The 2009 Elections to the European Parliament, Basingstoke: Palgrave.

Mamadouh, V. and Raunio, T. (2003) 'The committee system: powers, appointments and report allocation', Journal of Common Market Studies, 41(2): 333-351.

Marsh, M. (1998) 'Testing the second-order election model after four European elections', British Journal of Political Science, 28(4): 591-607.

Matland, R.E. and Studlar, D.T. (2004) 'Determinants of Legislative Turnover: A CrossNational Analysis', British Journal of Political Science, 34(1): 87-108.

Meserve, S., Daniel Pemstein, William T. Bernhard (2009) 'Political Ambition and Legislative Behavior in the European Parliament', The Journal of Politics, 71(3): 1015-32. 
Neuhold, C. (2001) 'The "Legislative Backbone" keeping the Institution upright? The Role of European Parliament Committees in the EU Policy-Making Process', European Integration Online Papers, 10, http://eiop.or.at/eiop/texte/2001-010a.htm.

Nugent, N. (1995) The Government and Politics of the European Union, $3^{\text {rd }}$ edn, Basingstoke: Macmillan

Nugent, N. (1999) The Government and Politics of the European Union, $4^{\text {th }}$ edn, Basingstoke: Macmillan

Nugent, N. (2010) The Government and Politics of the European Union, $7^{\text {th }}$ edn, Basingstoke: Palgrave

Pedersen, M.N. (1979) 'The Dynamics of European Party Systems: Changing Patterns of Electoral Volatility’ European Journal of Political Research, 7(1): 1-26.

Reif, K. and Schmitt, H. (1980) 'Nine Second-Order National Elections: A Conceptual Framework for the Analysis of European Election Results', European Journal of Political Research, 8(1): 3-44.

Ringe, N. (2010) Who Decides and How? Preferences, Uncertainty, and Policy Change in the European Parliament, Oxford: Oxford University Press.

Scarrow, S.E. (1997) 'Political Career Paths and the European Parliament', Legislative Studies Quarterly, 22(2): 253-263. 
Schlesinger, J.A. (1966) Ambition and Politics: Political Careers in the United States, Rand McNally: Chicago, Illinois.

Strøm, K. (1990), ‘A Behavioral Theory of Competitive Political Parties', American Journal of Political Science, 34(2): 565-98.

Verzichelli, L. and Edinger, M. (2005) 'A Critical Juncture? The 2004 European Elections and the Making of a Supranational Elite', Journal of Legislative Studies, 11(2): 254-274.

Westlake, M. (1994a) A Modern Guide to the European Parliament, London: Pinter.

Westlake, M. (1994b) Britain's Emerging Euro-elite? The British in the Directly-Elected European Parliament, 1979-1992, Aldershot: Dartmouth.

Whitaker, R. (2011) The European Parliament's Committees: National party influence and legislative empowerment, London: Routledge.

Woldendorp, J., Keman, H. and Budge, I. (2000) Party Government in 48 Democracies (1945-1998): Composition, Duration, Personnel, Dordrecht, Netherlands: Kluwer Academic.

Wood, A. (1984) The Times Guide to the European Parliament 1984, London: Times Books.

WORD COUNT: 7968 